\title{
Carpathian Basin climate according to Köppen and a clothing resistance scheme
}

\author{
Ferenc Ács ${ }^{1}$ (D) Annamária Zsákai ${ }^{2}$ (D) $\cdot$ Erzsébet Kristóf ${ }^{3,4}$ (D) $\cdot$ Amanda Imola Szabó ${ }^{1}$ (D) Hajnalka Breuer ${ }^{1}$ (D)
}

Received: 31 October 2019 / Accepted: 26 March 2020 / Published online: 19 April 2020

(C) The Author(s) 2020

\begin{abstract}
The Carpathian Basin climate in the time period 1971-2000 is analyzed in terms of the results obtained by the Köppen method and a clothing resistance scheme. A clothing resistance scheme is based on human body energy balance considerations taking into account human interperson variations as simply as possible. Interperson variations are considered by estimating human body somatotypes using the Heath-Carter somatotype classification method. Non-sweating, walking humans in outdoor conditions are treated. Environmental and human data are taken from the CarpatClim dataset and a Hungarian human dataset, respectively. Though the biophysical bases of the methods are completely different, the spatial structure of thermal climates expressed in terms of Köppen climate types and the clothing resistance parameter $r_{\mathrm{cl}}$ are basically similar. A clothing resistance scheme creates more information than the Köppen method not only in mountain, plateau areas but also in lowlands. It is shown that more human thermal climate categories can refer to one Köppen climate formula irrespective of which Köppen formulae are considered. The magnitude and area heterogeneity of $r_{\mathrm{cl}}$ is strongly sensitive to human somatotype changes. A clothing resistance scheme cannot be used in classroom applications; it needs to be drastically simplified while maintaining its sensitivity to somatotype changes in order to be competitive with the Köppen method.
\end{abstract}

\section{Introduction}

The Köppen method $(1884,1900,1918,1936)$ is the most popular climate classification method, even in modern times (Kottek et al. 2006; Rubel and Kottek 2011; Rubel et al. 2017) because of its simplicity. Its rules are biogeographically based following the thermal zones of the Earth's biomes. This is excellently illustrated in Fig. 1 of Köppen's (1900) work; because of its importance, it is also presented in this study (Fig. 1).

Ferenc Ács

acs@ caesar.elte.hu

1 Faculty of Science, Department of Meteorology, Eötvös Loránd University, Pázmány Péter sétány 1/A, Budapest 1117, Hungary

2 Faculty of Science, Department of Human Anthropology, Eötvös Loránd University, Pázmány Péter sétány 1/C, Budapest, Hungary

3 Faculty of Science, Department of Meteorology, Eötvös Loránd University, Pázmány Péter sétány 1/A, Budapest, Hungary

4 Faculty of Science, Excellence Center, Eötvös Loránd University, Brunszvik utca 2, Martonvásár, Hungary
The figure together with the rules used unequivocally shows that vegetation's thermal climate considerations are the basis of Köppen method.

Clothing resistance as thermal climate indicator is introduced into the science of climate classification somewhat later (e.g., Auliciems and de Freitas 1976; de Freitas 1979). In these analyses, clothing resistance characterizes clothing heat insulation obtained from energy balance considerations of the human body - air environment system. In all cases, the "average human" is treated as either being in standing (Auliciems and Kalma 1979) or in walking (Błażejczyk et al. 2010, 2013) state in outdoor conditions.

So far, the Köppen method is not related to any clothing resistance treatment. Such a comparative treatment is justified not only because of the lack of such an analysis but also because both approaches reflect thermal climate aspects. Köppen does this from the point of view of macroscale vegetation types, clothing resistance method from the point of view of humans. The aims of this study are as follows: a) to describe the Carpathian Basin's climate by using Köppen's method, b) to characterize the Carpathian Basin's climate in terms of clothing resistance, and c) to compare Köppen's climate types with results obtained using a clothing resistance scheme. Humans are treated in natural outdoor conditions, 


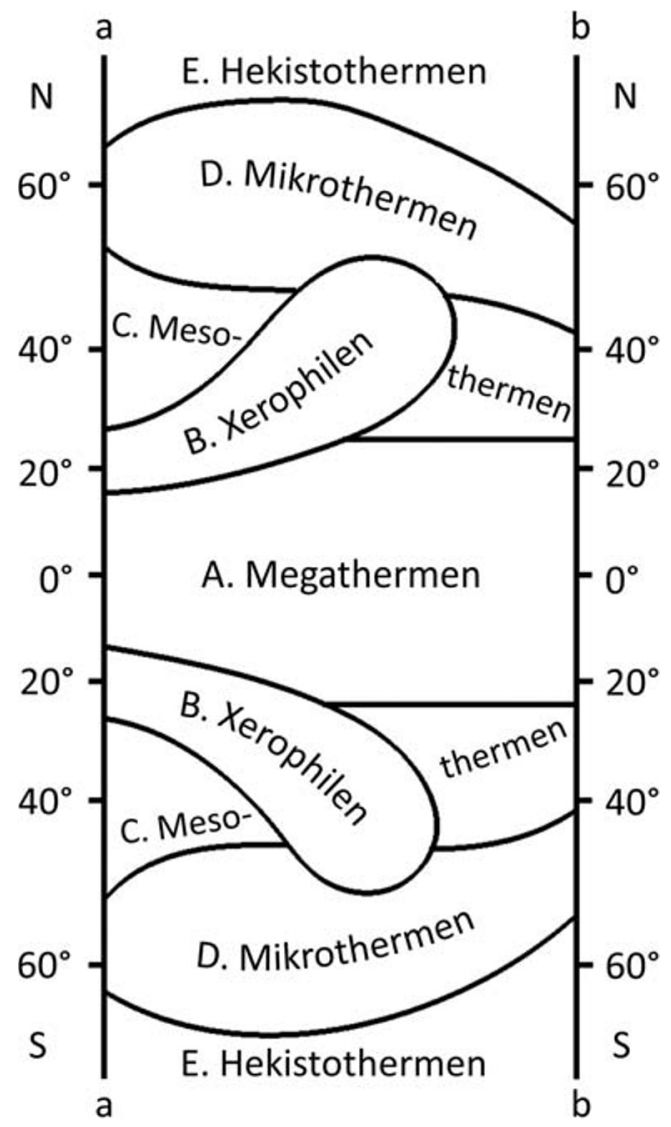

Fig. 1 Sketch of the Earth's thermal zones according to Köppen's (1900) work

where they are walking without sweating. Different human somatotypes exist. Somatotypes are characterized by applying the Heath-Carter somatotype classification method (Carter and Heath 1990). The region considered is the Carpathian Basin, more precisely, the region encompassed by the CarpatClim dataset.

Table 1 Köppen's (1936) climate types according to Kottek et al. (2006). $C=$ temperate, $D=$ boreal, $E=$ alpine, $T_{\text {hot }}=$ temperature of the hottest month, $T_{\text {cold }}=$ temperature of the coldest month, $T_{\text {mon10 }}=$ number of the months with average temperature above $10^{\circ} \mathrm{C}, P_{\text {sdry }}=$ precipitation of the driest summer month, $P_{\mathrm{wdry}}=$ precipitation of the driest winter
The methods used are briefly presented in Section 2. The region is briefly introduced in Section 3. Basic information regarding the datasets used can be found in Section 4. The results are discussed in Section 5, the main focus being on the comparison of the Köppen climate map and the thermal climates obtained by a clothing resistance scheme. The results referring to this comparison are presented in Section 5.4. Concluding remarks are given in Section 6.

\section{Methods}

All the methods considered were formed around the middle of the twentieth century. It should be noted that they were developed completely independently of each other. First, the climate classification method, then the human-related method will be presented.

\subsection{The Köppen method}

The Köppen method (1884, 1900, 1918, 1936), (Geiger 1961) is the result of the development over an extensive period. Here, only those parts of the scheme that are presented are indispensable from the point of view of the treatment. The criteria of climate types (Köppen formulae) that appeared in the region considered are presented in Table 1.

\subsection{The clothing resistance scheme}

The clothing resistance parameter is an equally environmental and human-specific parameter. It can be derived on the basis of steady-state human body energy balance considerations. Using energy balance equations for human skin — clothing interface and for clothing - air environment interface it can be expressed as follows:

month, $P_{\text {swet }}=$ precipitation of the wettest summer month, $P_{\text {wwet }}=$ precipitation of the wettest winter month. Summer/winter is defined as the warmer/cooler 6-month period of ONDJFM and AMJJAS. Categories signed with bold letters occur in the Carpathian region

\begin{tabular}{|c|c|c|c|c|c|}
\hline \multicolumn{3}{|c|}{ Letters } & \multicolumn{3}{|l|}{ Criteria } \\
\hline 1 & 2 & 3 & 1 & 2 & 3 \\
\hline \multirow[t]{3}{*}{$\mathrm{C}$} & $\mathrm{s}$ & $\mathbf{a}$ & $-3<T_{\text {cold }}<18$ and $T_{\text {warm }}>10$ & $P_{\text {sdry }}<40, P_{\text {sdry }}<\frac{P w w e t}{3}$ & $T_{\text {warm }} \geq 22$ \\
\hline & $\mathrm{w}$ & $\mathbf{b}$ & & $P_{\text {wdry }}<\frac{P_{\text {swet }}}{10}$ & $T_{\text {warm }}<22, T_{\text {mon } 10} \geq 4$ \\
\hline & f & c & & neither (s) nor (w) & $T_{\text {warm }}<22,1 \leq T_{\text {mon } 10}<4$ \\
\hline \multirow[t]{4}{*}{ D } & $\mathrm{s}$ & $\mathbf{a}$ & $\mathrm{T}_{\text {cold }} \leq-3$ and $T_{\text {warm }}>10$ & $P_{\text {sdry }}<40$ and $P_{\text {sdry }}<\frac{P w w e t}{3}$ & $T_{\text {warm }} \geq 22$ \\
\hline & & $\mathbf{b}$ & & & $T_{\text {warm }}<22, T_{\text {mon } 10} \geq 4$ \\
\hline & $\mathrm{w}$ & c & & $P_{\mathrm{wdry}}<\frac{P_{\text {swet }}}{10}$ & neither (a) nor (b), $T_{\text {cold }} \geq-38$ \\
\hline & $\mathbf{f}$ & d & & neither $(\mathrm{s})$ nor $(\mathrm{w})$ & neither (a) nor (b), $T_{\text {cold }}<-38$ \\
\hline ET & & & $0<T_{\text {warm }}<10$ & & \\
\hline
\end{tabular}


$r_{c l}=\rho \cdot c_{p} \cdot \frac{T_{S}-T_{a}}{M-\lambda E_{s d}-\lambda E_{r}-W}-r_{H r} \cdot\left[\frac{R_{n i}}{M-\lambda E_{s d}-\lambda E_{r}-W}+1\right]$,

where $\rho$ is the air density $\left(\mathrm{kgm}^{-3}\right), c_{\mathrm{p}}$ is the specific heat at constant pressure $\left(\mathrm{Jkg}^{-1}{ }^{\circ} \mathrm{C}^{-1}\right), r_{\mathrm{Hr}}$ is the combined resistance for expressing the thermal radiative and convective heat exchanges $\left(\mathrm{sm}^{-1}\right), T_{\mathrm{S}}$ is the skin temperature $\left({ }^{\circ} \mathrm{C}\right), T_{\mathrm{a}}$ is the air temperature $\left({ }^{\circ} \mathrm{C}\right), R_{\mathrm{ni}}$ is isothermal net radiation flux density $\left(\mathrm{Wm}^{-2}\right), M$ is the metabolic heat flux density $\left(\mathrm{Wm}^{-2}\right), \lambda \mathrm{E}_{\mathrm{sd}}$ is the latent heat flux density of dry skin $\left(\mathrm{Wm}^{-2}\right), \lambda \mathrm{E}_{\mathrm{r}}$ is the respiratory latent heat flux density $\left(\mathrm{Wm}^{-2}\right)$, and $W$ is the mechanical work flux density $\left(\mathrm{Wm}^{-2}\right)$ corresponding to the activity under consideration. $r_{\mathrm{cl}}$ is estimated for a non-sweating human walking in outdoor conditions at a speed of $1.1 \mathrm{~ms}^{-1}\left(4 \mathrm{~km} \cdot \mathrm{h}^{-1}\right)$. During walking, skin temperature is $34{ }^{\circ} \mathrm{C}$; the human body is completely covered by clothing, which sticks closely to the skin. The SI unit of $r_{\mathrm{cl}}$ is $\left(\mathrm{sm}^{-1}\right)$ but is usually expressed in (clo). If $1(\mathrm{clo})=0.155$ $\left(\mathrm{m}^{2} \mathrm{KW}^{-1}\right)$ and if $\mathrm{r}_{\mathrm{cl}} /\left(\rho \cdot \mathrm{c}_{\mathrm{p}}\right)=1(\mathrm{clo})$, then $\mathrm{r}_{\mathrm{cl}}=1.2\left(\mathrm{kgm}^{-3}\right) \cdot 1004$ $\left(\mathrm{Jkg}^{-1} \mathrm{~K}^{-1}\right) \cdot 0.155\left(\mathrm{~m}^{2} \mathrm{KW}^{-1}\right)=186.74\left(\mathrm{sm}^{-1}\right)$.

The human body is represented as single segment using a onenode model (Katić et al. 2016). According to Weyand et al. (2010) $M$ can be expressed as follows:

$M=M_{b}+M_{w}$,

where $M_{\mathrm{b}}$ is the basal metabolic rate (W) (sleeping human) and $M_{\mathrm{w}}$ is the metabolic rate for walking. $M_{\mathrm{b}}$ is parameterized according to Mifflin et al.'s (1990) formula, while $M_{\mathrm{w}}$ is expressed after Weyand et al.' (2010) results as follows:

$M_{w}=1.1 \cdot \frac{3.80 \cdot M_{b o} \cdot\left(\frac{L_{b o}}{100}\right)^{-0.95}}{A}$,

where $M_{\mathrm{bo}}$ is the body mass $(\mathrm{kg}), L_{\mathrm{bo}}$ is the body length $(\mathrm{cm})$, and $A$ is body surface $\left(\mathrm{m}^{2}\right)$. $A$ is estimated after the following well-known Dubois and Dubois (1915) formula:

$A=0.2 \cdot M_{b o}^{0.425} \cdot\left(\frac{L_{b o}}{100}\right)^{0.725}$

As we see, $M$ varies from human to human, or from human group to human group, that is, it can be related to somatotype. Latent heat and mechanical work flux densities can be simply parameterized via $M$ according to Campbell and Norman (1998) and Auliciems and Kalma (1979), respectively.

$R_{\mathrm{ni}}$ and $r_{\mathrm{Hr}}$ are important environmental forcings related to solar radiation, cloudiness, air temperature, air humidity, and wind velocity. Both variables are parameterized after theoretical treatments given in Campbell and Norman's book (1998). A full description of the model can be found in the work of Ács et al. (2019). In this study, $r_{\mathrm{cl}}$ is viewed as a thermal regulator, which can equally have both heating and cooling effects on the human body in cold and heat stresses, respectively, to reach thermal equilibrium between the clothed human body and the outdoor environment. Accordingly, in the case of heat excess (high $T_{\mathrm{a}}$ and $R_{\mathrm{ni}}$ values), it is negative, and inversely, in the case of heat deficit (low $T_{\mathrm{a}}$ and $R_{\mathrm{ni}}$ values), it is positive. When the human body and the environment are in thermal balance, often called thermal neutrality or comfort, $r_{\mathrm{cl}}$ is zero or close to zero. This interpretation of $r_{\mathrm{cl}}$ is new.

\subsection{Heath-Carter somatotype classification method}

The somatotyping method classifies the human morphological body shape by using three components, namely, the component of endomorphy (the component of relative fatness), the component of mesomorphy (the component of skeletomuscular robustness), and the component of ectomorphy (the component of linearity). The strength of all these components ranges on a scale from 1 (the lowest) to 12 (the highest). The continuous scales of the components provide a unique method to quantify morphological body shape diversity in a three-dimensional system. The somatotype of each human can be represented by the combination of endomorphic, mesomorphic, and ectomorphic components. The dominance relations of the components determine the type of body shape (e.g., if the mesomorphy component is significantly higher than the other two components, it is a mesomorphic somatotype, in which somatotype can be characterized by greater than average bone and muscular development in the body). The combination 444 is called "central", since in this case, there is no dominant component. Anthropometric body dimensions are used to calculate the component values. The two-dimensional Reuleaux triangle (the so called somatochart) can be used to graphically represent the individual, three-dimensional somatotypes (Siders and Rue 1992).

Somatotype changes with age, varies according to gender (from puberty), and geographic variation (race) in the human populations and shows a relationship with chronic illness and lifestyle characteristics (the level of physical activity, the type of sport activity performed, and diet). Adult females can be usually characterized by the endomorphic somatotype, while the somatotype of the average adult male is usually central or ectomorph. Extreme somatotypes (when one of the components reaches at least 8 on the scale and the other two components are no higher than 4) are very rare in general populations. However, every somatotype can be found in all populations and population subgroups, only the frequency of the somatotype categories varies with age, gender, geographic variation, and lifestyle factors.

\section{Region}

The region considered is presented in Fig. 2 together with the elevation data and the geographical designations used in the 
Fig. 2 The region of the CarpatClim dataset with its basic elevation data and major geographical designations used in the study

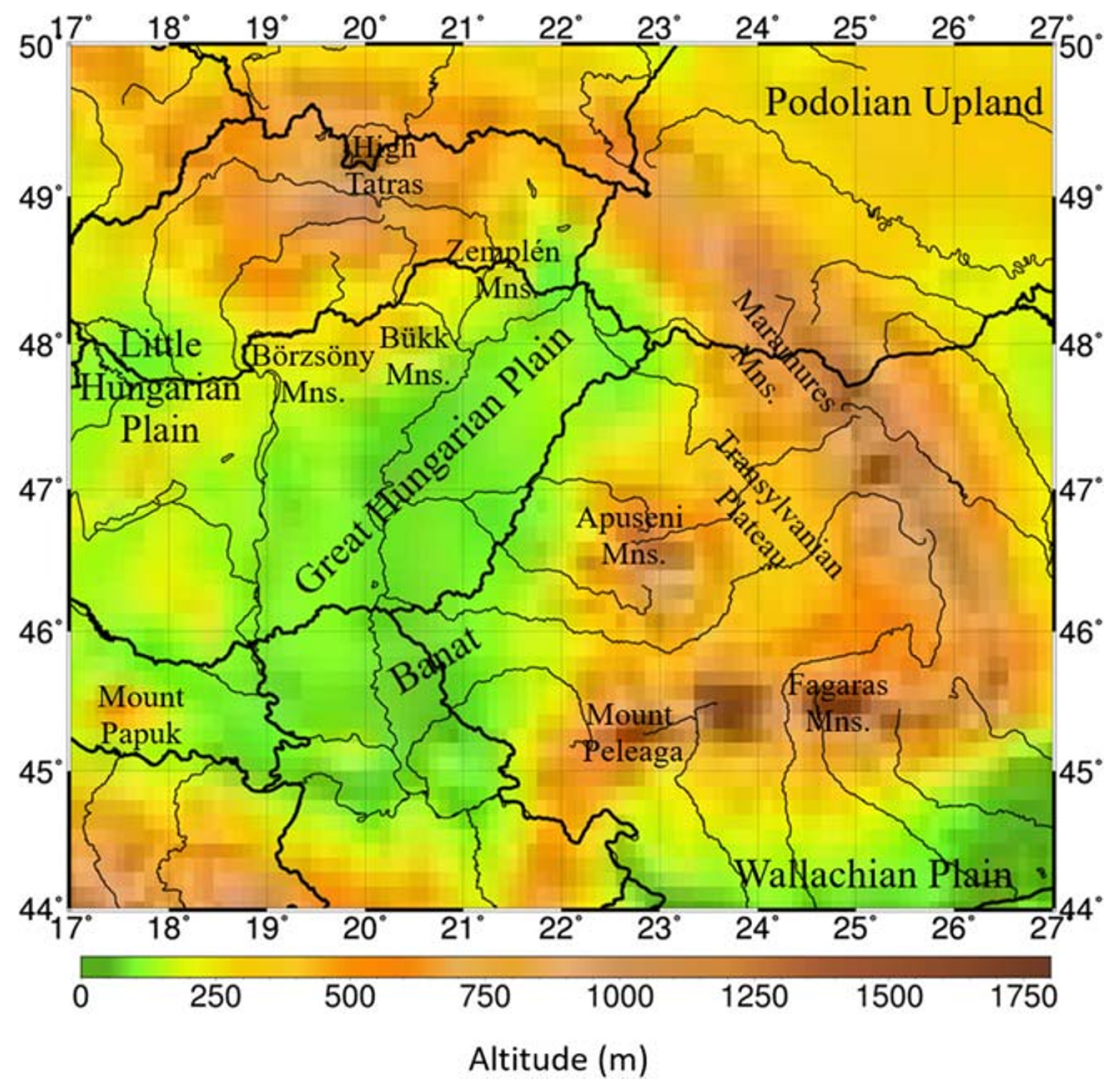

study. It is located between $17^{\circ}$ and $27^{\circ} / 44^{\circ}$ and $50^{\circ}$ longitude/latitude lines containing the Carpathian Basin almost completely.

The relief is heterogeneous, including lowland, for instance, the Little Hungarian Plain or Wallachian Plain, higher plateau areas, such as the Transylvanian Plateau or Podolian Plateau, and mountains, such as the Apuseni or Făgăras Mountains.

\section{Data}

\subsection{Climate data}

Climate data are taken from the CarpatClim dataset, which refer to the period 1961-2010 and possess a spatial resolution of $0.1^{\circ} \times 0.1^{\circ}$ (about $10 \mathrm{~km} \times 10 \mathrm{~km}$ ) and a temporal resolution of 1 day. The region contains 6161 grid points. The data are quality controlled and homogenized by applying the MASH method (Szentimrey 2013). Interpolation and gridding procedures are performed by using the MISH method (Szentimrey and Bihari 2013). A detailed description of the CarpatClim dataset characteristics is given in the work of Spinoni et al. (2015).

In this study, among the data available, global radiation, cloud cover, air temperature, vapor pressure, and $10 \mathrm{~m}$ wind speed data are used. Monthly values are calculated from daily values; thirty-year means are calculated for the central period 1971-2000. The $r_{\mathrm{cl}}$ values are calculated by using the monthly values of the meteorological variables.

\subsection{Human data}

Human body characteristics are taken from a Hungarian human dataset (Utczás et al. 2015; Zsákai et al. 2015; Bodzsár et al. 2016) constructed at the Department of Biological Anthropology, Eötvös Loránd University, Budapest, Hungary. The dataset contains data of more than 3000 Hungarian children and adults, among them about 2000 Hungarian children, and about 1000 Hungarian adults. The determination of somatotype is carried out for 1847 children and 898 adults. From this set of adults, we chose an endomorphic, mesomorphic, and endomorphic humans. The basic human characteristics of these persons are presented in Table 2.

It is to be mentioned that for a walking human, the total energy flux density $M$ increases going from ectomorphic $M^{\text {ecto }}$ through mesomorphic $M^{\text {meso }}$ to endomorphic $M^{\text {endo }}$ somatotype, that is $M^{\text {ecto }}<M^{\text {meso }}<M^{\text {endo }}$. The body mass excesscaused by fat mass excess or skeletomuscular mass excess or both - always increases the energy flux density of the human body. 
Table 2 The basic human characteristics of an endomorphic female, mesomorphic male, and ectomorphic female

\begin{tabular}{lllllll}
\hline Humans & $\begin{array}{l}\text { Age } \\
(\text { years })\end{array}$ & $\begin{array}{l}\text { Body mass } \\
\left(\mathrm{M}_{\mathrm{bo}}\right)(\mathrm{kg})\end{array}$ & $\begin{array}{l}\text { Body length } \\
\left(\mathrm{L}_{\mathrm{bo}}\right)(\mathrm{cm})\end{array}$ & $\begin{array}{l}\text { Basal metabolic flux } \\
\text { density }\left(\mathrm{Wm}^{-2}\right)\end{array}$ & $\begin{array}{l}\text { Walking energy flux } \\
\text { density }\left(\mathrm{Wm}^{-2}\right)\end{array}$ & $\begin{array}{l}\text { Total energy flux density } \\
\left(\mathrm{Wm}^{-2}\right)\end{array}$ \\
\hline $\begin{array}{c}\text { Endomorphic } \\
\text { female }\end{array}$ & 24 & 132.5 & 168.5 & 43.6 & 144.8 & 188.5 \\
$\begin{array}{c}\text { Mesomorphic } \\
\text { male }\end{array}$ & 19 & 82.0 & 172.6 & 45.4 & 105.7 & 151.1 \\
$\begin{array}{c}\text { Ectomorphic } \\
\text { female }\end{array}$ & 19 & 46.0 & 166.1 & 41.0 & 80.7 & 121.2 \\
\hline
\end{tabular}

\section{Results}

First, the results were obtained by the Köppen method, then the Heat-Carter somatotype classification results of the three humans considered and finally the clothing resistance scheme results of the three humans discussed are considered. At the end, the results obtained by the two methods are comparatively analyzed.

\subsection{Köppen climate map}

The Köppen climate map in the region and time period considered is presented in Fig. 3.
Köppen clearly shows the importance of the relief in the formation of thermal climate. Lowland is represented by the climate formulae $C f a(\mathrm{C}$, warm temperate; $\mathrm{f}$, no seasonality in the annual course of precipitation; a, hot summer) and $C f b$ (b, warm summer). In plateau areas, $C f b$ and/or $D f b$ (D, boreal) can be found, while in the mountains $D f b, D f c$ (c, cool summer), and ET (Tundra) climate types can be found. Climate type $C f c$ is located only in one pixel very close to or on Mount Papuk. The impact of relief can be unequivocally observed via $C f a \rightarrow C f b \rightarrow D f b \rightarrow D f c \rightarrow E T$ climate formula transitions in Southern Romania going from the River Danube to the Făgăras Mountains. Note that all climate formulae contain the symbol "f," so, the climates differ only from the point of view of their thermal states. The thermal homogeneity of all
Fig. 3 Area distribution of Köppen climate types in the CarpatClim dataset region for the period 1971-2000

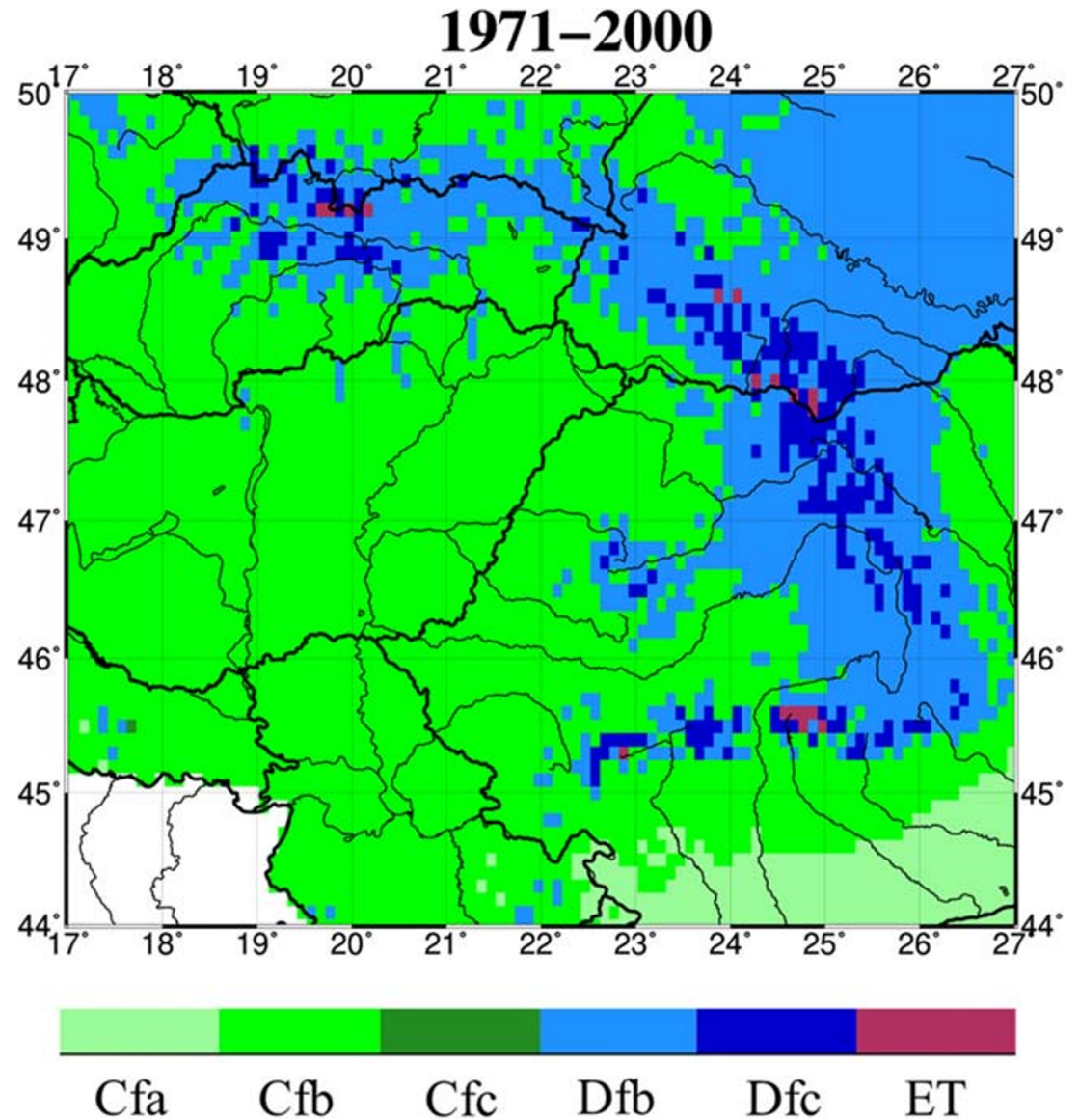


Fig. 4 Somatotype representation of the three humans considered according to the Heath-Carter somatotype classification method
- Endomorphic female

- Mesomorphic male

- Ectomorphic female

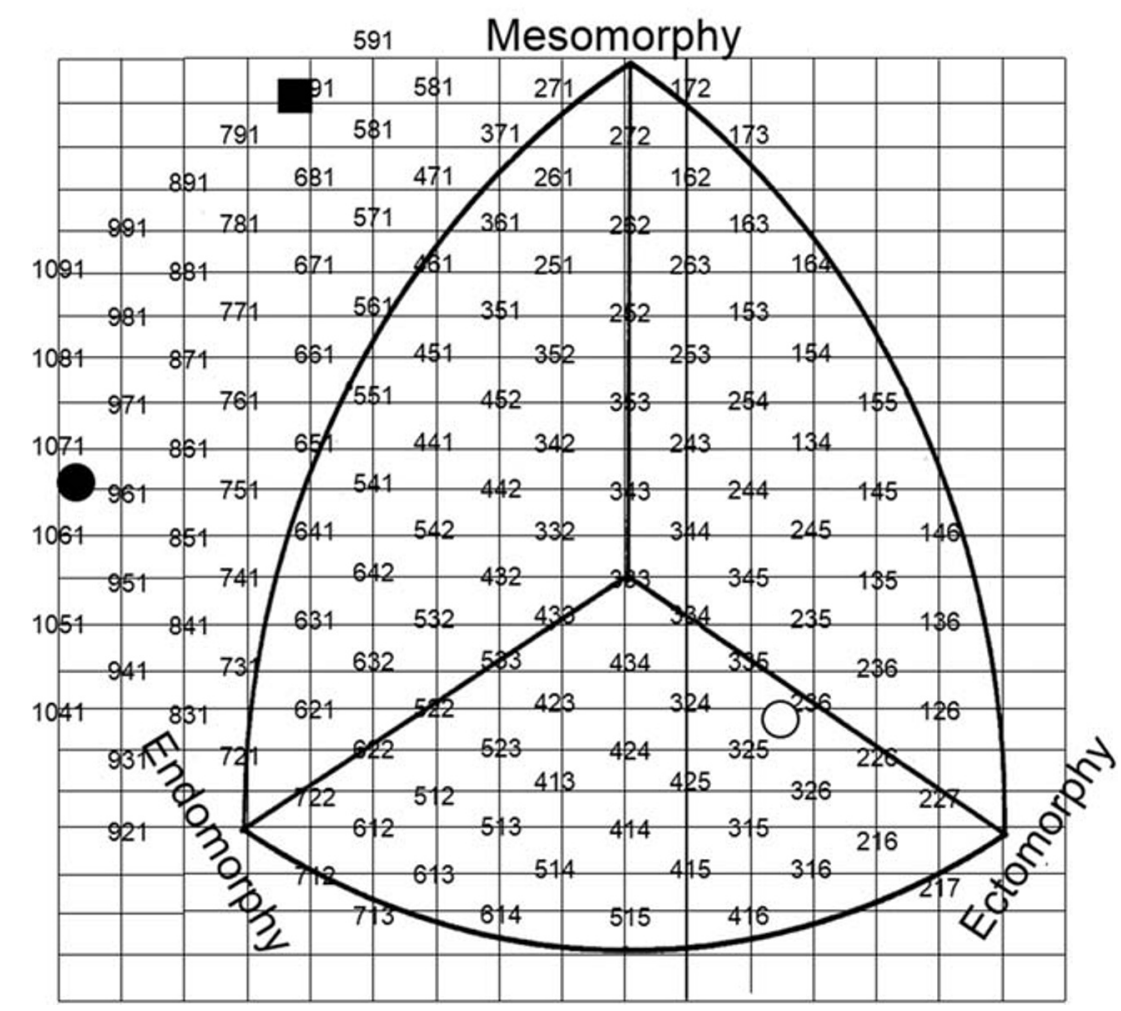

Hungarian lowland areas is conspicuous. Some locations with large thermal contrasts are also registered. So, in the regions of Mount Peleaga and the Făgăras Mountains the formulae ET and $C f b$ can be found in adjacent pixels. Similarly, large thermal contrasts (adjacent pixels with climate formulae ET and $D f b$ ) are located in the regions of the Maramures Mountains and the High Tatras.

\subsection{Heat-Carter somatotype classification results}

The humans presented in Table 1 are classified according to the Heath-Carter somatotype classification method. The results are presented in Fig. 4.

An endomorphic female, a mesomorphic male, and an ectomorphic female are used for the comparison. The endomorphic somatotype is typical for adult females; however, in this case, not only was the endomorphic component (relative fatness) extremely high in the studied woman's somatotype, the mesomorphic component was also higher than average, meaning this somatotype is a mesomorphic endomorph type according to the Heath-Carter categorization. A similar tendency can be found in the case of the mesomorphic male, one of the components (mesomorphy, the skeletomuscular robustness component) was extremely high and dominated the body shape, another component was also higher than average (endomorphy), while the third component (ectomorphy) was extremely low, meaning this is an endomorphic mesomorph somatotype. The ectomorph female's body shape was dominated by the ectomorphy component (linearity); the two other components are similar. Since all the somatotypes can be found in every subgroup of human populations, this somatotype is absolutely normal in adult females as well, although its frequency is usually very low in women; in those subgroups of humans whose relative fatness is usually high, their body shape can be usually described as endomorph somatotype. By considering the body shapes of all the three studied subjects, we can state that two of them could be characterized by extreme somatotypes: their linearity is small and the robusticity of their body is extremely high.

\subsection{Thermal climate maps in terms of clothing resistance}

Annual mean and annual range clothing resistance maps are considered. Annual mean clothing resistance maps in the region and time period considered for humans of ectomorphic, mesomorphic, and endomorphic somatotypes are presented in Fig. 5a, b, and c, respectively. Figs. 5 and 6 are constructed by 
a)

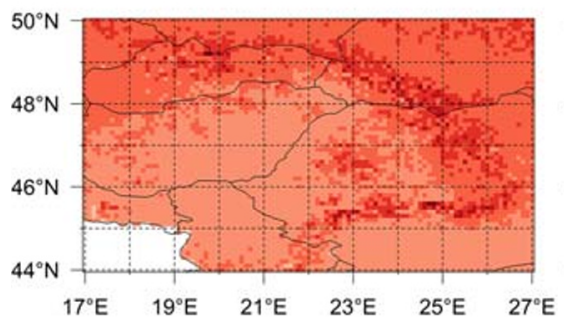

b)

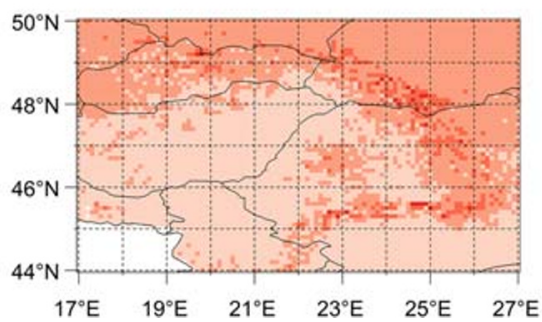

c)

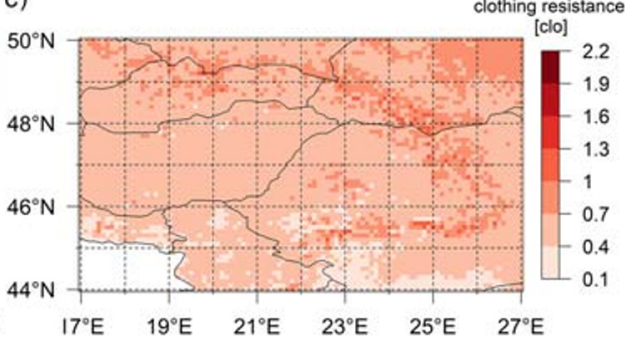

Fig. 5 Area distribution of annual mean clothing resistance values in the CarpatClim dataset region for the period 1971-2000 for an a ectomorphic, b mesomorphic, and $\mathbf{c}$ endomorphic human

R programming language ( $\mathrm{R}$ Core Team 2019) and by functions from packages maps (Brownrigg et al. 2018) and fields (Nychka et al. 2017).

The impact of relief on the formation of human thermal climate can also be observed. In lowland areas, human thermal climate is mostly spatially homogeneous and a weak somatotype dependence can be observed. This is clearly visible going from ectomorphic (0.4-0.7 (clo)) through mesomorphic to endomorphic humans $\left(0.1-0.4\right.$ (clo)). The lowest $r_{\mathrm{cl}}$ values for ectomorphic (0.4-0.7 (clo)) and endomorphic humans $(0.1-0.4$ (clo)) are located in the Great Hungarian Plain and close to the River Danube in the Wallachian Plain, respectively. Note that the Banat region can be experienced as warm as the Wallachian Plain irrespectively of the human somatotype.

In plateau areas, human thermal climate is somewhat cooler, that is, higher $r_{c l}$ values can be found with respect to lowland areas. This can be easily observed by comparing $\mathrm{r}_{\mathrm{cl}}$ values, for instance, in the Great Hungarian Plain and Podolian Plateau for an endomorphic human, or, in the Great Hungarian Plain and Transylvanian Plateau for an ectomorphic human. In this case, thermal climate area heterogeneity is somewhat larger for ectomorphic than for an endomorphic human.

$r_{\mathrm{cl}}$ values are the highest in the mountains. They are between 1 and 2 (clo) for ectomorphic and between 0.7 and 1.3 (clo) for endomorphic humans. Thermal climate area heterogeneity decreases unequivocally going from ectomorphic through mesomorphic to endomorphic humans. The impact of mountains on human thermal climate can also be observed in Hungary. This can be seen in the Zemplén Mountains, the
Bükk Mountains, and the Börzsöny Mountains for an ectomorphic and mesomorphic human, where the $r_{\mathrm{cl}}$ values in some pixels are above 1 (clo). For an endomorphic human, the same phenomenon is hardly visible.

Large thermal contrast areas can be found on Mount Papuk, Mount Peleaga, Făgăras Mountains, the Maramures Mountains, and the High Tatras. Thermal contrast is larger for an ectomorphic than for an endomorphic human.

Annual range clothing resistance maps for humans of ectomorphic, mesomorphic, and endomorphic somatotypes are presented in Fig. 6a, b, and c, respectively.

In lowland and plateau areas, the annual range of $r_{\mathrm{cl}}$, $\mathrm{dr}_{\mathrm{cl}}$ is unequivocally larger than in high mountainous areas irrespective of the somatotype considered. Of course, $\mathrm{dr}_{\mathrm{cl}}$ values for ectomorphic humans are larger than those for mesomorphic and endomorphic humans. The largest $\mathrm{dr}_{\mathrm{cl}}$ values appeared on the Transylvanian Plateau for the ectomorphic somatotype, in some areas they were between 2.8 and 3.1 (clo). The lowest $\mathrm{dr}_{\mathrm{cl}}$ values range between 1 and 1.3 (clo), these can be found in the region of Mount Peleaga, the Făgăras Mountains, the Maramures Mountains, the High Tatras, and the Bükk Mountains. The areas with the largest thermal contrast are located on the northern side of the Făgăras Mountains at the boundary with the Transylvanian Plateau region. Here the lowest/ highest $\mathrm{dr}_{\mathrm{cl}}$ values are around 1/3 (clo), respectively. In lowlands, the area heterogeneity of $\mathrm{dr}_{\mathrm{cl}}$ values is rather low, the values range between 1.3 and 1.6 (clo) for endomorphic and between 1.3 and 1.9 (clo) for ectomorphic humans. a)

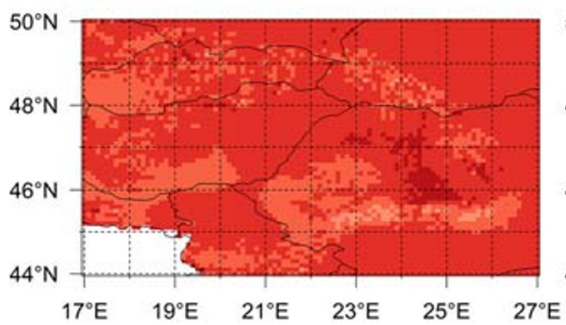

b)

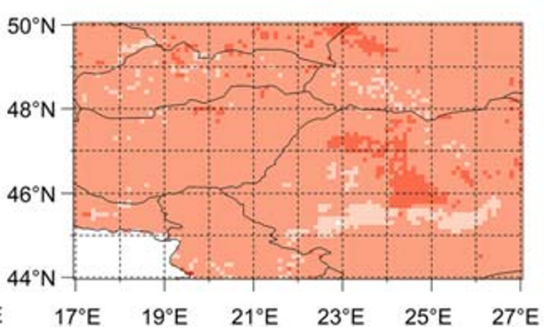

C)

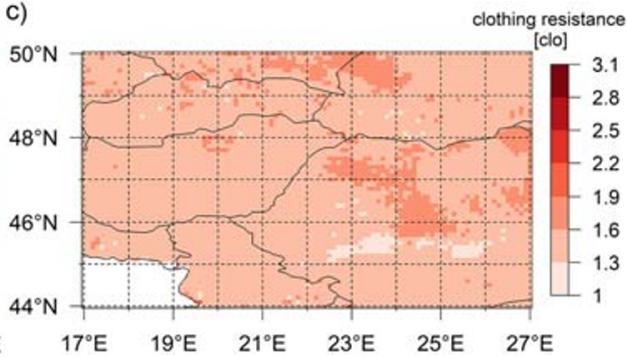

Fig. 6 Area distribution of annual range values of clothing resistance in the CarpatClim dataset region for the period 1971-2000 for an a ectomorphic, $\mathbf{b}$ mesomorphic, and $\mathbf{c}$ endomorphic human 


\subsection{Comparison of the Köppen climate map with maps representing the annual mean and range of $r_{\mathrm{cl}}$}

As it was mentioned, the Köppen climate map gives more information related to thermal than to moisture characteristics of climate. This is especially valid for the Carpathian Basin region; therefore, the Köppen climate map (Fig. 3) will be briefly compared with annual $r_{\mathrm{cl}}$ and $\mathrm{dr}_{\mathrm{cl}}$ maps (Figs. 5 and 6). Both methods reveal strong impact of relief on formation of thermal climate, but the amount of information produced by the clothing resistance scheme is larger than the amount of information obtained by the Köppen method. This is valid not only for lowlands but also for plateau and mountainous areas. What can be immediately observed is that more human thermal climates can be assigned to one Köppen formula irrespective of which is considered. For instance, on the territory of the Podolian Plateau, Köppen's climate formula is $D f b$. This climate type is experienced differently by ectomorphic, mesomorphic, and endomorphic humans. Annual mean $r_{\mathrm{cl}}$ values can vary between 0.4 and 1.6 (clo), the corresponding annual range $\mathrm{dr}_{\mathrm{cl}}$ values being between 1.3 and 2.5 (clo) for all three somatotypes. The climate of the Banat region, as one of the warmest sub-regions, is spatially homogeneous according to Köppen (climate formula $C f b$ ); nevertheless, the corresponding human thermal climates show less territorial homogeneity. Similar cases can be observed on the territories of the Transylvanian Plateau and in the mountains. Köppen can hardly distinguish climate between the North Hungarian Mountains (the Börzsöny, Bükk and Zemplén Mountains) (climate formula $D f b$ ) and lowland (climate formula $C f b$ ); this distinction is much easier to notice in the case of human thermal climates, especially in the case of ectomorphic somatotype.

Besides the differences, there are also similarities. According to Köppen, the Wallachian Plain (climate formula $C f a$ ) and Podolian Upland (climate formula $D f b$ ) differ markedly in terms of their climates. Similarly, large differences exist in annual mean $r_{\mathrm{cl}}$ values for all three somatotypes. Areas characterized by large thermal contrast are equally well reproduced by Köppen and by the clothing resistance scheme. There are also "mixed" cases, when both differences and similarities can be observed. According to Köppen, there is no difference between the Little Hungarian Plain's and the Great Hungarian Plain's climates (climate formula $C f b$ ). Human thermal climates can differ; these differences are observable for the ectomorphic somatotype, but by changing the somatotype toward the endomorphic, these differences become less and the differences disappear for the endomorphic somatotype (Fig. 5).

\section{Conclusion}

The Carpathian Basin region's thermal climate for the time period 1971-2000 is analyzed by applying the Köppen method and a clothing resistance scheme. Köppen's main climate classes, except main climate $B$ (arid climate), are distinguished by using different monthly air temperature (temperature of the warmest or coldest month) thresholds, which are related to geographical boundaries of some biomes; therefore, Köppen method can be treated as vegetation- and temperature-based global classification system. In the region of the Carpathian Basin, Köppen's method distinguishes climates only from the point of view of thermal regime since there are no differences regarding precipitation regime (the letter " $\mathrm{f}$ " is in all pixels). The third letter in the climate formula characterizes the strength of thermal state in summer. Note that the third letter is also related to the vegetation (Köppen 1936; page C 17). The clothing resistance parameter $r_{\mathrm{cl}}$, as an output of the clothing resistance scheme, can be used as a human thermal climate indicator (e.g., Robaa and Hasanean 2007). The scheme assumes that humans are walking at a speed of $1.1 \mathrm{~m} \cdot \mathrm{s}^{-1}$ without sweating, but their somatotypes can differ. Human somatotypes are characterized by the Heath-Carter somatotype classification method (Carter and Heath 1990). Environmental and human data are taken from CarpatClim (Spinoni et al. 2015) and a Hungarian human dataset (Zsákai et al. 2015), respectively.

Both methods reflect unequivocally the impact of relief on the formation of thermal climate. They also give a good reproduction of locations with large thermal contrasts, such as Mount Papuk, Mount Peleaga, the Făgăras Mountains, the Maramures Mountains, and the High Tatras. Both methods suggest that areas with largest thermal contrasts are located at the boundary between the Transylvanian Plateau and the Făgăras Mountains. However, thermal climate expressed in terms of $r_{\mathrm{cl}}$ contains more information not only in lowland but also in plateau regions and in the mountains. Note that more human thermal climate categories can refer to one Köppen climate formula. Area heterogeneity of human thermal climate types is unequivocally larger for ectomorphic than for endomorphic humans. Area heterogeneity of human thermal climates is much larger in the mountains than in the lowland.

It should be noted that the Köppen method is much simpler than the human thermal climate model. It not only needs less input data but also its biophysics is simpler. Human thermal climate modeling will be competitive with the Köppen method if its biophysics based on human body energy balance treatment is simplified. The competitiveness requires drastic simplifications on one hand, and on the other hand, the unequivocal effect of human body somatotype on the thermal state experienced has to be maintained because of its enormous importance. 
Funding information Open access funding provided by Eötvös Loránd University (ELTE).

Open Access This article is licensed under a Creative Commons Attribution 4.0 International License, which permits use, sharing, adaptation, distribution and reproduction in any medium or format, as long as you give appropriate credit to the original author(s) and the source, provide a link to the Creative Commons licence, and indicate if changes were made. The images or other third party material in this article are included in the article's Creative Commons licence, unless indicated otherwise in a credit line to the material. If material is not included in the article's Creative Commons licence and your intended use is not permitted by statutory regulation or exceeds the permitted use, you will need to obtain permission directly from the copyright holder. To view a copy of this licence, visit http://creativecommons.org/licenses/by/4.0/.

\section{References}

Ács F, Kristóf E, Zsákai A (2019) New clothing resistance scheme for estimating outdoor environmental thermal load. Geographica Pannonica 23(4):245-255. https://doi.org/10.5937/gp23-23717

Auliciems A, de Freitas CR (1976) Cold stress in Canada. A human climatic classification. Int J Biometeorol 20(4):287-294

Auliciems A, Kalma JD (1979) A climatic classification of human thermal stress in Australia. J Appl Meteorol 18:616-626

Błażejczyk K, Broede P, Fiala D, Havenith G, Holmér I, Jendritzky G, Kampmann B, Kunert A (2010) Principles of the new universal thermal index (UTCI) and its application to bioclimatic research in European scale. Miscellanea Geographica 14:91-102

Błażejczyk K, Jendritzky G, Bröde P, Fiala D, Havenith G, Epstein Y, Psikuta A, Kampmann B (2013) An introduction to the universal climate index (UTCI). Geogr Pol 86(1):5-10

Bodzsár É, Fehér VP, Vadászi H, Zsákai A (2016) A női nemi hormonok szintje és a testzsírosság kapcsolata pubertáskorú leányoknál (Sex hormonal levels and body fatness in pubertal girls). Anthropologiai Közlemények 57:51-60

Brownrigg R, Minka TP, Deckmyn A (2018) Maps: draw geographical maps. R package version 3.3.0. Original S code by R.a. Becker, a.R. Wilks URL: https://CRAN.R-project.org/package=maps

Campbell GS, Norman JM (1998) An introduction to environmental biophysics, second edition, Springer, New-York, ISBN-0-387-94937-2

Carter JL, Heath BH (1990) Somatotyping: development and applications. Cambridge University Press, Cambridge, p 503

de Freitas CR (1979) Human climates of northern China. Atmos Environ 13:71-77. https://doi.org/10.1016/0004-6981(79)90246-4

Dubois D, Dubois EF (1915) The measurement of the surface area of man. Arch Intern Med 15:868-881. https://doi.org/10.1001/ archinte.1915.00070240077005

Geiger R (1961) Überarbeitete Neuausgabe von Geiger, R: KöppenGeiger/Klima der Erde. (Wandkarte 1:16 Mill.) - Klett-Perthes, Gotha

Katić K, Li R, Zeiler W (2016) Thermophysiological models and their applications. A review. Build Environ 106:286-300. https://doi.org/ 10.1016/j.buildenv.2016.06.031

Köppen W (1884) Die Wärmezonen der Erde, nach der Dauer der heissen, gemässigten, und kalten Zeitund nach der Wirkung der Wärme auf die organische Welt betrachtet. Meteorol Z 1:215-226

Köppen W (1900) Versuch einer klassifikation der klimate, vorzugsweise nach ihren beziehungen zur pflanzenwelt. Geogr Zeitschrift 6(593611):657-679
Köppen W (1918) Klassifikation der klimate nach temperatur niederschlag und jahresablauf. Petermanns Geogr Mitt 64(193203):243-248

Köppen W (1936) The geographic system of climates (original: das geographische system der Klimate). In: Köppen W and Geiger R (eds) Handbuch der Klimatologie, Bd. 1, Teil C, Borntraeger, Berlin, $44 \mathrm{pp}$

Kottek M, Grieser J, Beck C, Rudolf B, Rubel F (2006) World map of the Köppen-Geiger classification updated. Meteorol Z 15(3):259-263. https://doi.org/10.1127/0941-2948/2006/0130

Mifflin MD, St Jeor ST, Hill LA, Scott BJ, Daugherty SA, Koh YO (1990) A new predictive equation for resting energy expenditure in healthy individuals. Am J Clin Nutr 51:241-247. https://doi.org/ 10.1093/ajen/51.2.241

Nychka D, Furrer R, Paige J, Sain S (2017) Fields: tools for spatial data. R package version 9.9. URL: https://cran.r-project.org/web/packages/ fields/index.html. https://doi.org/10.5065/D6W957CT

R Core Team (2019) R: a language and environment for statistical computing. R Foundation for statistical computing, Vienna. URL: http:// www.R-project.org/

Robaa SM, Hasanean HM (2007) Human climates of Egypt. Int J Climatol 27:781-792. https://doi.org/10.1002/joc.1434

Rubel F, Kottek M (2011) Comments on "the thermal zones of the earth" by Wladimir Köppen (1884). Meteorol Z 20(3):361-365. https:// doi.org/10.1127/0941-2948/2011/0285

Rubel F, Brugger K, Haslinger K, Auer I (2017) The climate of the European Alps: shift of very high resolution Köppen-Geiger climate zones 1800-2100. Meteorol Z 26:115-125. https://doi.org/10.1127/ metz/2016/0816

Siders W, Rue M (1992) Reuleaux triangle somatocharts. Comput Biol Med 22(5):363-368. https://doi.org/10.1016/0010-4825(92)90024-H

Spinoni J, the CARPATCLIM project team (39 authors) (2015) Climate of the Carpathian region in 1961-2010: Climatologies and trends of ten variables. Int J Climatol 35:1322-1341. https://doi.org/10.1002/ joc.4059

Szentimrey T (2013) Multiple analysis of series for homogenization. MASH v3.03. In: Bihari Z: CARPATCLIM, climate of the Carpathian region, deliverable D2.10, final version of metadata per country of all national gridded datasets created within module 2 annex 3 - description of MASH and MISH algorithms, $100 \mathrm{pp}$

Szentimrey T, Bihari Z (2013) Meteorological interpolation based on surface homogenized data basis (M I S H v1.02), in: Bihari Z: CARPATCLIM, climate of the Carpathian region, deliverable D2.10, final version of metadata per country of all national gridded datasets created within module 2 annex 3 - description of MASH and MISH algorithms, $100 \mathrm{pp}$

Utczás K, Zsákai A, Muzsnai Á, Fehér VP, Bodzsár É (2015) Radiológiai és ultrahangos módszerrel végzett csontéletkor-becslések összehasonlító elemzése 7-17 éveseknél (the analysis of bone age estimations performed by radiological and ultrasonic methods in children aged between 7-17 year). Anthropologiai Közlemények 56:129-138

Weyand PG, Smith BR, Puyau MR, Butte NF (2010) The mass-specific energy cost of human walking is set by stature. J Exp Biol 213: 3972-3979. https://doi.org/10.1242/jeb.048199

Zsákai A, Mascie-Taylor N, Bodzsár ÉB (2015) Relationship between some indicators of reproductive history, body fatness and the menopausal transition in Hungarian women. J Physiol Anthropol 34(1): $35-42$

Publisher's note Springer Nature remains neutral with regard to jurisdictional claims in published maps and institutional affiliations. 